\title{
Syrphids (Diptera, Syrphidae) and coccinellids (Coleoptera, Coccinellidae) occurring in Myzus cerasi (F.) (Hemiptera) colonies on Prunus avium $\mathrm{L}$.
}

\author{
Elżbieta Wojciechowicz-Żytko
}

\author{
Department of Plant Protection \\ Faculty of Horticulture, University of Agriculture in Krakow \\ 29 Listopada 54, 31-425 Kraków, Poland \\ e-mail: ewojcie@ogr.ur.krakow.pl
}

\begin{abstract}
During the sampling period, 243 syrphid larvae belonging to seven species were collected from $M$. cerasi colonies on P. avium. Episyrphus balteatus Deg. and Epistrophe eligans (Harr.) were the most numerous species amongst the materials gathered, followed by Syrphus ribesii (L.) and S. vitripennis Meig. All of these species play an essential role in reducing M. cerasi populations. Amongst the Coccinellidae occurring in black cherry aphid colonies, Adalia bipunctata L. was the dominant species, while the subdominant was Coccinella septempunctata $\mathrm{L}$. and Propylaea quatuordecimpunctata (L.).
\end{abstract}

Key words: black cherry aphids, cherry trees, hoverflies, ladybirds

\section{INTRODUCTION}

The black cherry aphid Myzus cerasi $\mathrm{F}$. is one of the most important pests for both sweet and sour cherry plants. Aphids feed on the lower sides of the upper leaves of young trees; the leaves become severely curled, falling behind in their growth, and then remain black and dry. The yield may be reduced by as much as $30 \%$ (Vereščagina 1966, Karczewska 1970).

$M$. cerasi colonies are controlled by many predators, the most important and best known of which are Coccinellidae, and Syrphidae (Wnuk 1972, Malinowska 1979, Rakauskas 1984, Cichocka 1996, Francardi and Roversi 1997, 1998, WojciechowiczŻytko 2007).

The aim of this research was to determine the population dynamics and species composition of predatory insects (Syrphidae, Coccinellidae) associated with Myzus cerasi (F.) on Prunus avium $\mathrm{L}$.

\section{MATERIAL AND METHODS}

The experiment was carried out in the years 2000 and 2005 on Prunus avium L. (medium early 'Vega' cultivar), in cherry orchards located on a southern slope, surrounded by apple and plum trees in Branice. This experiment was a continuation of previous research made in several locations in the Krakow area on other cherry cultivars (Wojciechowicz-Żytko 2007).

Ten tips (young growths) were selected at random from every 10 trees from each orchard. Predatory syrphids and coccinellids on these tips were counted from April to July at weekly intervals. From the other (not selected) tips, syrphid larvae were collected from aphid colonies and reared separately in Petri dishes, fed daily with aphids until their emergence. Syrphidae adults were classified as different species based on the Bańkowska (1963), van Veen (2004) and Rotheray (1993) keys, and Coccinellidae based on the Bielawski (1959) key. 
The species domination of Syrphidae was determined based on Dickler (1968):

$$
\begin{aligned}
& >10 \% \text { eudominants } \\
& 5.1-10 \% \text { dominants } \\
& 2.1-5 \% \text { subdominants } \\
& 1.1-2 \% \text { recedents } \\
& <1 \% \text { subrecedents. }
\end{aligned}
$$

The constancy index of syrphid species was also defined, using the formula (Szujecki 1980):

$$
C=\frac{q}{Q} 100 \%
$$

where: $\mathrm{C}=$ constancy index, $\mathrm{q}=$ number of samples in which the species occurred,

$\mathrm{Q}=$ number of analysed samples.

The species domination of Coccinellidae was not determined due to the small amount of ladybirds collected.

\section{RESULTS AND DISCUSSION}

\section{Occurrence of Syrphidae}

During the sampling period, 267 syrphid larvae belonging to seven species were collected. A larger amount of Syrphidae was collected in the year 2000 (Tab. 1).

Episyrphus balteatus Deg. and Epistrophe eligans (Harr.) were the most numerous species amongst the materials gathered, followed by Syrphus ribesii (L.) and S. vitripennis Meig. (Fig. 1). The remaining species occurred in smaller numbers. Some species appeared only occasionally, eg. Sphaerophoria scripta (L.) in 2000, or Platycheirus scutatus (Meig.) in 2005. Based on the Petryszak (1982) dominance class, E. balteatus, E. eligans, $S$. ribesii and $S$. vitripennis were classified as eudominants, while $E$. corollae as subdominant or dominant, depending on the year of observation. According to Francardi and Roversi $(1997,1998)$ and Rakauskas (1984), each of these species plays an essential role in reducing $M$. cerasi populations.

The syrphid species identified during the experiment were similar to those found by Wojciechowicz-Żytko (2007) in previous years in M. cerasi colonies on P. avium. Wnuk (1972)

\begin{tabular}{|c|c|c|c|c|c|c|c|}
\hline & \multicolumn{2}{|c|}{2000} & \multicolumn{2}{|c|}{2005} & \multirow{2}{*}{$\begin{array}{c}\text { Total } \\
\text { number }\end{array}$} & \multirow{2}{*}{$\begin{array}{c}\text { Dominance } \\
\text { class }\end{array}$} & \multirow{2}{*}{$\begin{array}{c}\text { Constancy } \\
\text { index }\end{array}$} \\
\hline & Number & $\begin{array}{l}\text { Dominance } \\
\text { class }\end{array}$ & Number & $\begin{array}{c}\text { Dominance } \\
\text { class }\end{array}$ & & & \\
\hline Episyrphus balteatus (Deg.) & 68 & $\mathrm{Ed}$ & 25 & Ed & 93 & Ed & 100.0 \\
\hline Epistrophe eligans (Harr.) & 32 & $\mathrm{Ed}$ & 31 & Ed & 63 & Ed & 90.9 \\
\hline Syrphus ribesii (L.) & 17 & Ed & 14 & Ed & 31 & Ed & 63.6 \\
\hline Syrphus vitripennis Meig. & 16 & Ed & 13 & Ed & 29 & Ed & 45.5 \\
\hline Eupeodes corollae (Fabr.) & 7 & $\mathrm{Sd}$ & 8 & $\mathrm{D}$ & 15 & $\mathrm{D}$ & 27.3 \\
\hline Platycheirus scutatus (Meig.) & - & - & 10 & $\mathrm{D}$ & 10 & $\mathrm{Sd}$ & 18.2 \\
\hline Sphaerophoria scripta (L.) & 2 & $\mathrm{Re}$ & - & - & 2 & $\mathrm{Sr}$ & 9.0 \\
\hline Dead non-identyfied larvae & 15 & - & 9 & - & 24 & - & - \\
\hline Total & 157 & & 110 & & 267 & & \\
\hline
\end{tabular}
observed the occurrence of 12 species of Syrphidae in black cherry aphid colonies, while Malinowska (1979) found 15 species on sweet cherry and 12 on

Table 1. Species composition, dominance structure and constancy of syrphids occurring in Myzus cerasi colonies on sweet cherry

Ed - eudominants, D - dominants, $\mathrm{Sd}$ - subdominants, $\mathrm{Re}$ - recedents, $\mathrm{Sr}$ - subrecedents

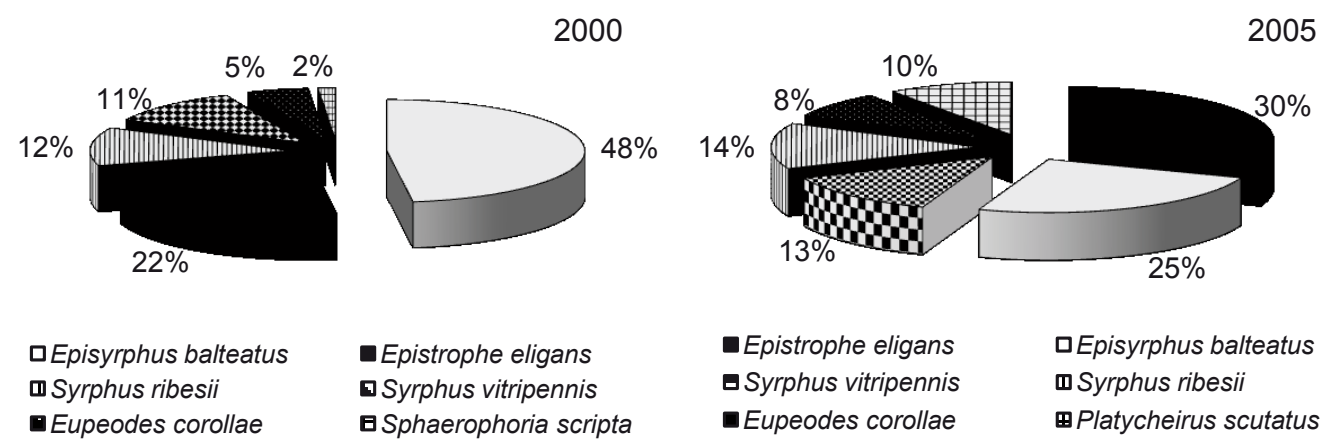

Figure 1. Species composition of aphidophagous Syrphidae collected from M. cerasi colonies in the years 2000 and 2005 

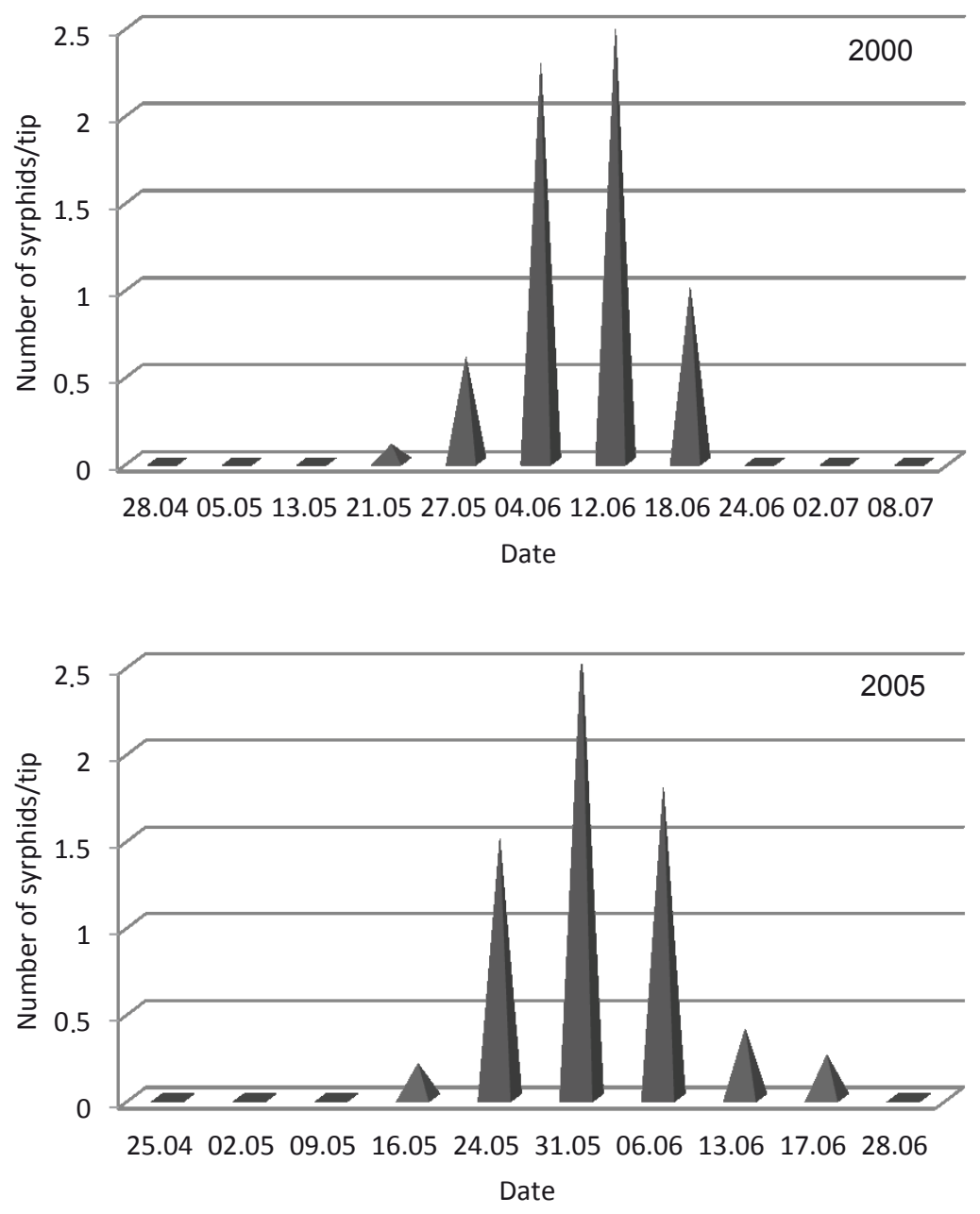

Figure 2. Population dynamics of Syrphidae

sour cherry, whereas Wojciechowicz-Żytko (2007) found 19 on $P$. avium and eight on P. cerasus.

$E$. balteatus and E. eligans were the species that occurred in particularly large numbers during the study. The constancy of those species was 100 and $90.9 \%$, respectively (absolutely constant species) (Szujecki 1980). S. ribesii and S. vitripennis were also numerous, with a constancy of 63.6 and $45.5 \%$, respectively (Tab. 1). These data demonstrate the large role of these species in regulating the population of M. cerasi. Eupeodes corollae, Platycheirus scutatus, and Sphaerophoria scripta were classified as accessory and incidental species.

The periods of the occurrence of larvae of the main syrphid species are shown in Figure 5.

The first syrphid individuals appeared in $M$. cerasi colonies in the second ten days of May (Fig. 2). Most of them constitute an early spring species-E. eligans (Fig. 5). This was between 14 and 20 days after the first aphids were noted. Afterwards, the syrphids appeared more numerously and their numbers had increased, reaching their maximum in late May/early June. Later, the population showed a declining tendency, completely disappearing at the end of June (Fig. 2).

According to Francardi and de Silva (1997), working on M. cerasi and its antagonists in central Italy, the amount of hoverflies reached the highest level in the second half of May.

\section{Occurrence of Coccinellidae}

In the years 2000 and 2005, 67 coccinellid larvae and adults belonging to five species were noted. Among the Coccinellidae occurring in M. cerasi colonies on $P$. avium Adalia bipunctata L. was the most numerous species $(49.3 \%)$, followed by Coccinella septempunctata L. in 2000 and Propylaea quatuordecimpunctata in 2005 (Tab. 2, Fig. 3). Other researchers (Rakauskas 1984, Francardi and de Silva 1997) had similar results.

The Coccinellidae were the first representatives of predacious entomofauna occurring in $M$. cerasi colonies. They presented on P. avium early in the season when aphid numbers were low (Fig. 4). They appeared in the beginning of May, a few days 
Table 2. Predatory coccinellids occurring in M. cerasi colonies on sweet cherry

\begin{tabular}{|c|c|c|c|c|c|c|}
\hline \multirow{2}{*}{ Coccinellidae species } & \multicolumn{2}{|c|}{2000} & \multicolumn{2}{|c|}{2005} & \multicolumn{2}{|c|}{ Total } \\
\hline & adult & larvae & adult & larvae & Number & $\%$ \\
\hline Adalia bipunctata $\mathrm{L}$. & 8 & 5 & 14 & 6 & 33 & 49.3 \\
\hline Propylaea quatuordecimpunctata (L.) & 2 & - & 4 & 1 & 7 & 10.4 \\
\hline Coccinella septempunctata $\mathrm{L}$. & 6 & 3 & 10 & 5 & 24 & 35.8 \\
\hline Coccinula quatuordecimpustulata (L.) & - & - & 2 & - & 2 & 2.9 \\
\hline Coccinella quinquepunctata $\mathrm{L}$. & - & - & 1 & - & 1 & 1.5 \\
\hline Total & 16 & 8 & 31 & 12 & 67 & 100.0 \\
\hline
\end{tabular}

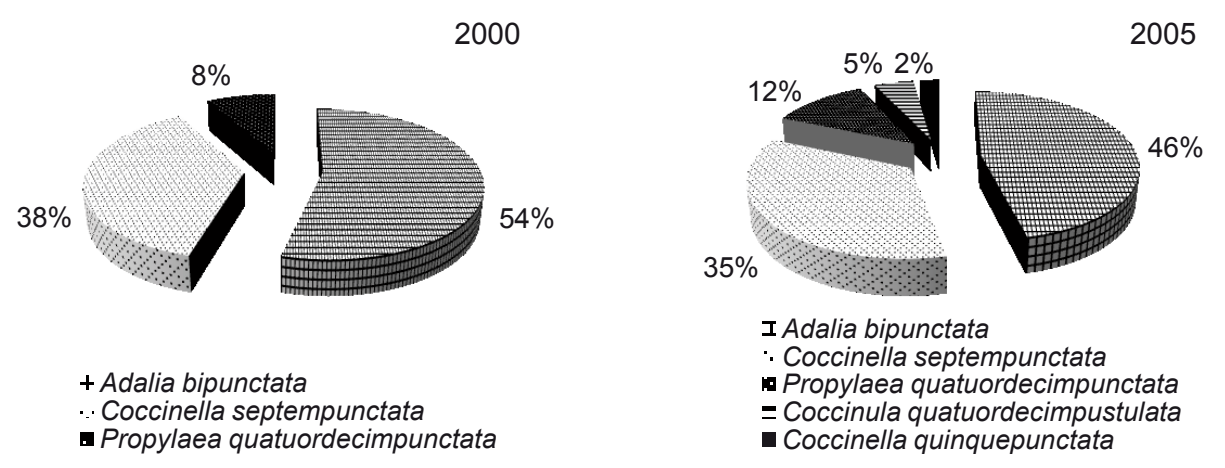

Figure 3. Species composition of Coccinellidae occurring in M. cerasi colonies

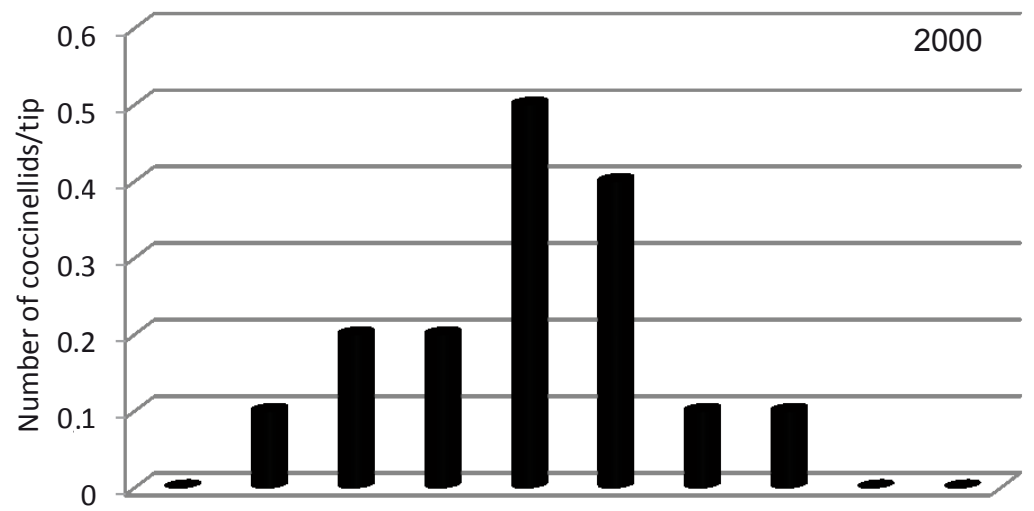

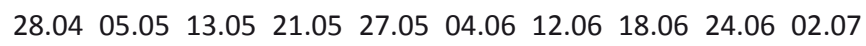

Date

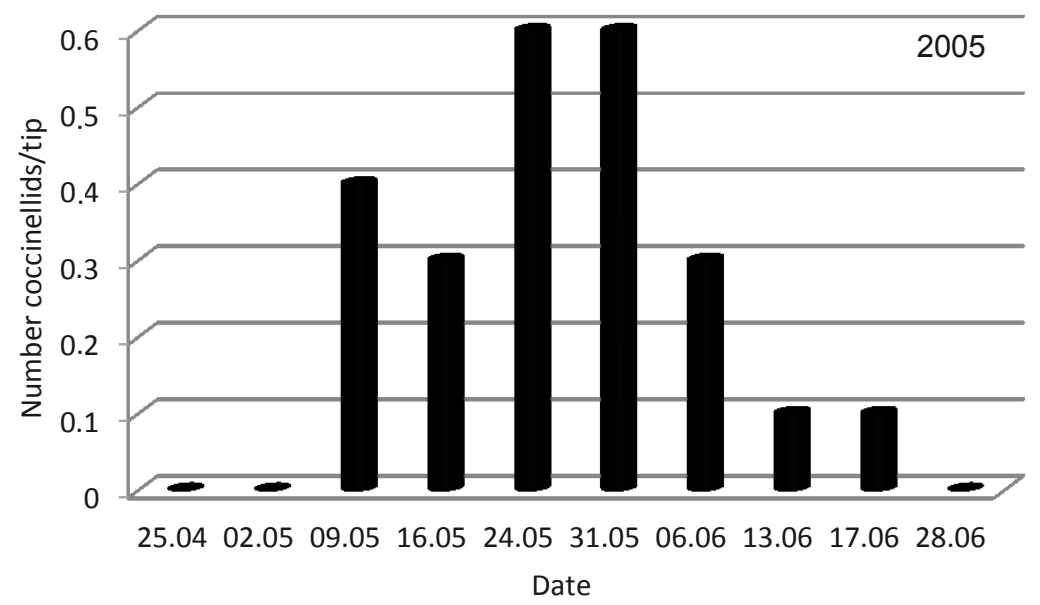

Figure 4. Population dynamics of Coccinellidae 


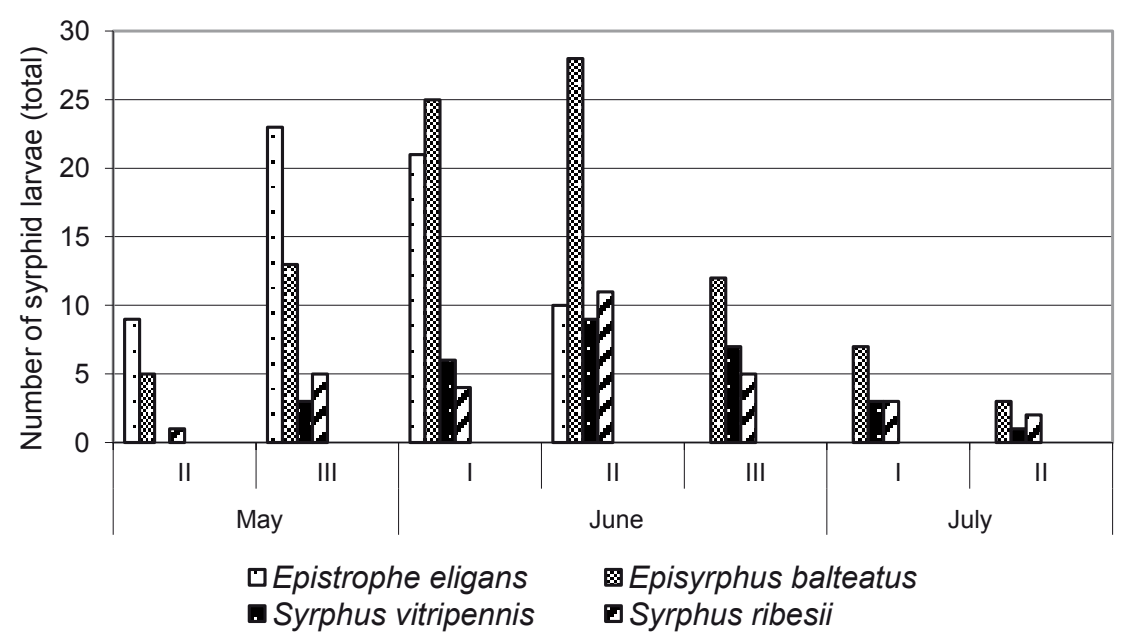

Figure 5. The occurrence of the main syrphid species during the years 2000 and 2005

after the aphids. From this time the population increased up to the third ten days of May, when the largest number of these insects was recorded. In the second ten days of June, a decrease in the coccinellid numbers was noted.

Because of the fact that Coccinellidae appear in early spring in aphid colonies and destroy the first fundatricae, they ought to be counted amongst the important groups of predators regulating aphid populations (Olszak 1978, Rakauskas 1984, Wojciechowicz-Żytko 2007). Olszak and Niemczyk (1986) stated that ladybirds are present in the largest numbers in orchards in early spring and in the summer on vegetables. According to Ganter and Jaśkiewicz (2001) and Wojciechowicz-Żytko (2004), ladybirds, especially Propylaea quatuordecimpunctata and Coccinella septempunctata, play a significant role in controlling the number of hazel aphids in early spring.

\section{CONCLUSIONS}

1. Seven syrphid species were noted in M. cerasi colonies. The most numerous were Episyrphus balteatus and Epistrophe eligans.

2. Coccinellidae was the first group of predators that appeared in M. cerasi colonies in the spring. The dominant species were Adalia bipunctata and Coccinella septempunctata.

3. Syrphidae and Coccinellidae play an essential role in regulating $M$. cerasi populations.

\section{REFERENCES}

BAŃKOWsKa R., 1963. Klucze do oznaczania owadów Polski. Część XXVII. Muchówki-Diptera. Zeszyt 24 Syrphidae. PWN, Warszawa, 236.
BielawsKi R., 1959. Biedronki - Coccinellidae. Klucze do oznaczania owadów Polski, XIX, 76, Warszawa, 92.

Cichocka E., 1996. Effect of natural enemies on aphid populations in young apple orchard. Aphids and Other Homopterous Insects 5: 37-45.

DiCKLER E., 1968. Untersuchungen zur Besiedlung von wiesennahen Leguminosenkulturen durch Rüsselkäfer. Zeit.f. angew. Ent. 55:129-192.

Francardi V., DE Silva J., 1997. On Myzus cerasi (F.) and its antagonists within timber plantations of Prunus avium L. in central Italy. Redia LXXX: 73-85.

Francardi V., Roversi P.F., 1997. Osservazioni sull'entomofauna fitifaga di Prunus avium L. in plantagioni da legno dell'Italia centro-settentrionale. Ann. Ist. Sper. Selv. XXV e XXVI: 399-412.

Francardi V., Roversi P.F., 1998. Variazioni stagionali in popolazioni di Myzus cerasi (F.) (Homoptera, Aphidoidea) e di suoi entomofagi In impianti di Prunus avium L. da legno. Annali Istituto Sperimentale per la Selvicoltura 29: 87-91.

Gantner M., JAŚKIEwicz B., 2001. Species composition of ladybirds (Coleoptera, Coccinellidae) on hazelnut plantations. Folia Hort. 13/1: 91-100.

KARCZEWSKA M., 1970. Z badań nad biologią mszycy wiśniowo-przytuliowej - Myzus cerasi (F.) (Homoptera, Aphididae) na wiśni. Pol. Pismo Ent. $\mathrm{XL} / 2$ : 345-359.

MalinowsKa D., 1979. Arthropod communities in terrestial ekosystem. Polish Academy of Sciences. Institute of Zoology. Memorabilia Zoologica: 30.

OlsZAK R., 1978. Drapieżne biedronkowate. In: „Biologiczne metody walki ze szkodnikami roślin”. J. Boczek and J. Lipa (eds), PWN, Warszawa: 253-266.

Olszak R., NiemczyK E., 1986. The predaceous Coccinellidae associated with aphid in apple orchards. Ekologia Polska 34(4): 711-721.

Petryszak B., 1982. Ryjkowce (Curculionidae, Coleoptera) Beskidu Sądeckiego. Rozpr. Nauk. UJ w Krakowie 68: 204. 
RAKAUSKAS R.P., 1984. Biologija i ekologija višnievoj tli v Litovskoj SSR. Trudy Akademii Nauk Litovskoj SSR, serija V, 4(88): 80-87.

Rotheray G., 1993. Colour guide to hoverfly larvae (Diptera, Syrphidae) in Britain and Europe. Dipterists Digests No. 9.

SzuJECKI A., 1980. Ekologia owadów leśnych. PWN, Warszawa.

VAN Veen M.P., 2004. Hoverflies of northwest Europe. KNNV Publishing, Utrecht: 254.

VerešČagina V.V., 1966. Višnievaja tlja Myzus cerasi Fabr. na čerešne i borb'a s nej v Moldavii. Trudy Moldavskovo naučno-issledovatel'skovo Instituta Sadovodstva, Vinogradarstva i Vinodelija 13: 39-52.

WNUK A., 1972. Badania nad składem gatunkowym drapieżnych bzygowatych (Syrphidae, Diptera) występujących w koloniach mszyc na drzewach i krzewach owocowych. Pol. Pismo Ent. 42: 235-247.

Wojciechowicz-Żytko E., 2004. Predators occurring in in Myzocallis coryli Goetze (Homoptera, Aphidodea) colonies on hazel (Corylus L.). J. Plant Protection Res. 44(3): 181-188.

Wojciechowicz-Żytкo E., 2007. Rola bzygowatych (Diptera, Syrphidae) i innych drapieżców w regulacji populacji mszycy wiśniowej - Myzus cerasi (F.)
(Homoptera, Aphidodea). Zesz. Nauk. AR w Krakowie, rozprawy, 443, 321: 92.

BZYGOWATE (DIPTERA, SYRPHIDAE) I BIEDRONKOWATE (COLEOPTERA, COCCINELLIDAE) WYSTECPUJACE W KOLONIACH MYZUS CERASI (F.) (HEMIPTERA) NA CZEREŚNI PRUNUS AVIUM L.

Streszczenie: W latach badań z kolonii mszycy wiśniowej żerującej na czereśni zebrano 243 larwy Syrphidae należące do 7 gatunków. Dominowały Episyrphus balteatus i Epistrophe eligans, mniej licznie występowały gatunki Syrphus ribesii i $S$. vitripennis. Gatunki te odgrywają dużą rolę w ograniczaniu populacji M. cerasi, można je uznać za typowe dla kolonii tej mszycy. W koloniach $M$. cerasi stwierdzono występowanie 5 gatunków biedronek - dominowały Adalia bipunctata L., Coccinella septempunctata L. i Propylaea quatuordecimpunctata (L.).

Received June 29, 2010; accepted October 17, 2011 